\title{
THE CIBERIA PROJECT: AN EXPERIMENT IN DIGITAL HERMENEUTICS
}

\author{
María Goicoechea de Jorge
}

\begin{abstract}
This article presents "Ciberia", a collection of electronic literature works in Spanish, housed in OdA 2.0., a learning objects' repository of the University Complutense of Madrid. The Ciberia project involves experimentation at the humanistic and technological level, since it deals with the challenge of archiving digitally-born literary works as well as with the archiving process itself, which we are carrying out in OdA 2.0, a data management system for the creation of learning objects repositories on the Web. OdA allows different researchers to work collaboratively in a simultaneous manner on the data base, they can not only introduce new objects but they can also modify the data model. This entourage allows us to create taxonomies in an inductive rather than deductive manner. The article covers aspects such as the objectives of the collection, the elaboration of Ciberia's bibliographic card, the process of metadata cleaning and reconciliation with other collections of the Linked Data cloud, such as the CELL Project, and Ciberia's research and pedagogical functions. Moreover, we will showcase some of its most representative literary works as we revise the process of the collection's creation.
\end{abstract}

KEYWORDS: Digital libraries. Ciberia. Digital hermeneutics. Data bases. Digital literature. Contemporary Spanish literature.

\section{Introduction}

Ciberia is a collection of electronic literature works in Spanish created by the LEETHI group (European Literatures from Text to Hypermedia), using OdA 2.0., a learning objects' repository built by ILSA research team at the Computing Sciences Faculty of the University Complutense of Madrid. Ciberia emerges from the need to make digital literature in Spanish more visible, report its development, and leave a trail that would compensate for its ephemeral quality. This collection is part of the research carried out by two research groups in Spain: ILSA, which has developed the software, and LEETHI, a group formed in 2000 by teachers from the Faculties of Philology and Education of the Complutense University of Madrid. Its members are specialized in different languages and their literatures (Spanish, English, French, German and Dutch). Their research activity has focused on the transformations of literary reading and writing rituals caused by digital technology and globalization. Their research

\footnotetext{
"Complutense University of Madrid, LEETHI and Hermeneia Research Groups, Madrid, Spain. E-mail: mgoico@filol.ucm.es
} 
methodology has been guided by the constant integration of literary, pedagogical and technological reflection, placing its emphasis on a transcultural perspective on hypermedia literary phenomena. With Ciberia, in particular, we want to pay attention to the development of digital literature in Spanish as a Pan-Hispanic phenomenon, which has created a new literary cybernation, with new contours, new heritage, new migrations and points of encounter.

So far we have collected a representative sample of 60 works to refine the data model. The selection was made trying to complement other directories as much as possible by introducing novelties, but we have also tried to keep a record of the most relevant pieces of digital literature in Spanish. Its aim is to present, in a didactic and attractive manner, a selection of digital literature to a general audience. We have in mind an audience of non-expert readers of digital literature, teachers and students of literature and language, media studies, who do not have a reference point for Spanish digital literature. For this purpose, Ciberia is both a repository and a digital library: its aim is to provide a repository of learning objects (the cards themselves and their enriched content) created by researchers, authors and students, and a gateway to e-Literature works and online resources, whose main purpose is to facilitate the integration of electronic literature in the classrooms.

\section{Digital Libraries for Strange Literature}

Ciberia is part of a bigger project called "Digital Library Between Two Centuries", a library gathering the text repertoires from two different turns of century that run parallel and in dialogue: "Mnemosine: The Library of Rare and Forgotten Literary Works of the Silver Age" (19 $19^{\text {th }}$ to $20^{\text {th }}$ centuries), which collects mostly the works of women authors that for ideological reasons had to go into exile or did not receive much critical attention, and "Ciberia: the Library of Electronic Literature in Spanish" $\left(20^{\text {th }}\right.$ to $21^{\text {st }}$ centuries $)$, which is in a way also a type of rare literature. The objectives of both libraries is to select, categorize, and make visible in digital format literary texts that belong to forgotten or unknown repertoires in order to allow the historiographical review of past historical periods or, in the case of Ciberia, record the evolution of a 
literary field from its inception. Another important premise for both libraries is to become fields of international experimentation for the creation of interoperable semantic networks through which a large group of scholars could generate innovative research and theoretical reading models for literary texts. Thus, the focus is not only philological but also technical, since the software implemented for their creation needs to facilitate cooperation and be capable of exporting and importing data from other repositories or libraries.

There has been a lot of discussion to distinguish between digital repositories, archives and libraries, and depending on the field of knowledge you are dealing with different expectations are raised regarding the data and metadata offered, the characteristics of the objects being referenced, their location inside a server, etc. In Ciberia's case, we have attempted to create something between a repository and a digital library: Our aim is to provide both a repository of learning objects created by researchers (the entry cards themselves and their enriched content), and a gateway to e-Literature works and online resources. We do not pretend to possess the files of the works we catalogue but we do provide a structure of documents whose purpose is to facilitate the integration of electronic literature in the classrooms, and document the change of paradigm from print to digital media.

We would like to preserve a testimony of artifacts that belong to a process to which we grant special significance: the development of a new form of literature. This task is not approached without critical awareness: some of the works in this collection, for instance, might seem amateurish but we think they have been necessary to develop the field we are documenting. We are also concerned with the very methods we are using to register this process of canon formation in digital literature and we have wondered if this cataloguing task is not performed with the mindset of an obsolete paradigm, this compulsive need to register everything. We have the feeling that this cataloguing craze somehow belongs to the print paradigm, its insatiable need to keep a record of every book, every text ever printed, independently of their potential use. 
In this respect, we have tried to be self-reflexive regarding the process of archiving, which is being transformed as we face the particularities of the digital object/process/event. Electronic textuality has become this liquid monster that challenges all attempts to confine it in encyclopedic definitions. However, we continue mapping the territory using Wikipedia and digital libraries. It is our way to make sense of our world: to create order out of chaos, to fight the threatening debris or "kipple", using Philip K. Dick's neologism, which keeps multiplying while we sleep. But as we proceed with our hectic ordering task in the digital domain something is transformed in the process. One of the crucial differences that archiving digital literature entails as opposed the print literature is the ephemeral nature of its pieces (due to changing operating systems, the obsolescence of software and physical devices, its porous, interconnected constitution, etc.). Therefore, it has become evident that in order to rescue as much information about those early works as we can we need to weave a network of cross-references, to organize our documents in ever growing constellations, that would testify in the first place for the work's existence and provide as accurate as possible a description of it in case of its disappearance. It has also become a new habit the use of tagging to make visible and locate documents. Free tagging, however, has posed a challenge to the old librarian, although we now perceive it as a necessary step, since old descriptive categories did not apply for electronic literature and critics needed to find their own expressions. We are still in Ciberia experimenting between free tagging and fixed categories, as we will see later.

In our preliminary assessment of the margins of Ciberia, we had to confront the most important question: Why Ciberia? Our main concern, therefore, has to do with the justification for a new electronic literature repository when there are already very important ones doing a wonderful job, and why around a specific language, when most of them are trying to open up to other cultures and to be more inclusive. In answer to our question, we felt that, if we wanted to contribute developing the field, choosing Spanish as a point of departure would fill in a gap from a philological perspective. Literary nations built around a language create a corpus of works in which frictions and borders can be explored. This area of research, which we call 
transliterature, is another field in which the LEETHI group has been working for a number of years now. Transliterature, not only understood as defining works which are complementarily supported by different media formats, but to refer to those literary works that use cyberspace to disseminate its cultural borders and identity, that become a space where cultural frictions and frames are continually being negotiated. So, we are talking about Transliterature as a phenomenon experienced by literature in the process of cybernetic globalization. We observe electronic literature works in Spanish to analyze the way in which the language becomes a literary medium across unexpected production and reception scenarios. We have in the collection many nomad authors writing in Spanish that have been affected by the present state of crisis and forced diaspora. For example, Hernán Casciari's blognovel Más respeto que soy tu madre is an interesting example of a work written in a very local Buenos Aires dialect that has become a global phenomenon, even beyond cyberspace, becoming one of those peculiar cases of digitally-born works that have become famous outside cyberspace, transformed into a popular theatre play, print novel and future cinema project. Thus, Spanish is the point of departure but not of destination since Ciberia references other works which also introduce or are translated in other languages.

There are other collections of Spanish Digital Literature, however, we feel that there is still ample space to complement their entries: pioneering collections, such as those of the NT2 the ELO, and Hermeneia have relatively few entries in Spanish, which is normal since their scope is international. The Biblioteca Virtual Miguel de Cervantes has a collection of electronic literature in Spanish, but this one only includes twentytwo narrative works, leaving electronic poetry outside! As a response to this situation, writers of electronic literature themselves, such as Belén Gache, have felt the need to assemble their own collections ${ }^{1}$. The ELMCIP has a growing collection of digital literature in Spanish, in part feeding from the contents of Ciberia, among other databases, artists' webpages, and online magazines dedicated to curate electronic literature. Our aim is to continue enriching this collection and to be part of the CELL

\footnotetext{
${ }^{1}$ See "Sociedad Lunar: Literatura expandida": <http://sociedadlunar.org/obras.php>. 
consortium, the network which will provide access to many digital literature collections around the globe.

Ciberia's architechture is indebted to many of these sites, from which we have gathered ideas regarding the disposition of information in the repository. Following the ELMCIP's example, for instance, we have created a database where we can upload all kinds of materials and documents that can be used to integrate e-literature in our curricula: critical works, student works, organized constellations of entries around a topic, etc.

\section{An Experiment in Digital Hermeneutics: A Data Management System in the Cloud}

The archiving process entails a close reading of the works, an interpretation, as well as a reflection regarding the modes of communicating and disseminating those interpretations. The choices in the configuration of the data-model are never trivial, they are always oriented to facilitate the retrieval of information, and thus, they always spring from our construction of an ideal reader and researcher of electronic literature. Digital technology has radically altered the way we create communities of readers since it has become the very fabric upon which we construct those networks, amplifying their reach, but sometimes also intruding upon the communication process, or weakening the ties among members. As Rafael Capurro has observed, the very notion of "network" has crystallized as the central metaphor for contemporary societies.

The leading modern pre-understanding of the engine as a metaphor for the process of social construction has been substituted by the one of the network understood as technology and as a medium of communication (CAPURRO, 2010).

We are learning how to deal with the technology that so affects the development of our field. In order to do that one has to participate in all the stages of the network construction, beginning with its database environment. The Ciberia project also 
involves experimentation with the archiving process itself, which we are carrying out in OdA 2.0, a data management system for the creation of learning objects repositories collaboratively on the Web. Spanish computer scientists from the ILSA research group ${ }^{2}$ (UCM) have developed this software to create repositories of digital learning objects, where teachers can upload their course materials so that other teachers or students can reuse them. OdA has also been used to construct digital museums, digital libraries or other type of digital collections. Its essential feature is that it allows researchers to work collaboratively directly on the web on their data model. So it is not a program that you can download on a computer or server like DSpace or ContentDM to construct your archive but it is a web service that allows several people to work on the metadata and the data model at the same time from distinct locations.

There are, of course, different levels for the users, which reproduces the hierarchy of readers inside a reading community (from expert to novice readers): superadministrators, who can see and change nearly everything (within the constraints of the program itself); administrators, who can upload and change their own entries (thought for authors, or other collaborators who want to upload data); and users, who have read-only access (you can leave Ciberia open or give access only to registered users).

From the technological perspective, we have approached the creation of the collection from a different angle than other repositories. The most important change is that the repository can be modified by several people, at the same time, in all the states of the repository progress. The system regenerates the navigation hierarchy and search form to the new collection structure, this element allows Ciberia to be a live project that can be expanded or modified for several years. OdA 2.0 is a web system with PHP language and MySQL database for server and HTML-CSS for client. Actually there is a new project that extends OdA's work. This new project, called Clavy, is a RIA (Rich Internet Application) which uses Google's GWT API to create a new interface and provide tools that allow the integration in a modern

\footnotetext{
${ }^{2}$ See http://ilsa.fdi.ucm.es/ilsa/ilsa.php
} 
Glassfish Java server (which can use php also) and a MySql database mapped by JPA technology. The new version is just finished and it is now being tested. It will allow us to import and export metadata from different databases and file metadata containers. It has solved some structural problems that we have encountered with the search engine. We expect to move our data to the new system to be able to share our content with other databases.

\section{In Search of a Data Model}

As we have already mentioned, OdA allows different researchers to work collaboratively in a simultaneous manner on the data base. They can not only introduce new objects but they can also modify the data model. They can add fields, delete them, move them to different sections of their taxonomy, make the fields visible, navigable, and extensible, create controlled vocabularies or open text fields, etc. This entourage allows us to create taxonomies in an inductive rather than deductive manner. Thus we go from the particular case to the general one, and we obtain the model after archiving a significant number of works. For example, we have needed to add tags which we have not found in other glossaries, such as "Gamebased drama" or "Gameformances", to describe the work carried out by the collective Yoctobit (http://yoctobit.wordpress.com/mlr/), or to introduce "interactive cinema" as a genre inside Digital Literature to accommodate examples of interactive video on webpages, as the reusable piece "Mindstorming" (http://www.mindstorming.tv/) seems to demand.

It is important to keep in mind that we do not have as many records as the other repositories, so for us the taxonomy has not emerged already and we cannot consider it stabilized. If we try to use the same taxonomy as the NT2, for example, we find for example that many categories do not have a representative work in Spanish, or, we can find no tag to describe certain works.

The flexibility of OdA is also a challenge for the creators of Ciberia. It is hard to grasp the implications that all the decisions you make will have on the search engine 
results. We are still experimenting with its possibilities for mapping the territory of Spanish e-literature.

In order to develop our data model, we have made an analysis of the main digital literature repositories (NT2, ELO, ELMCIP) and extracted what we liked about each of them:

- $\quad$ About the NT2 we found very didactic the taxonomy of tags it proposes: we have adapted most of its categories, but we have changed the name of "Interactivity" for "Rhetorical devices" (the lack of interactivity could be one device) and added the category of "Genre" as distinct to that of "Theme".

- We thought that such a taxonomy opens many questions and that the ELO collection keyword glossary was an efficient way to guide visitors through the collection.

- We also found very useful the idea of allowing researchers to upload their own content, and create personal pages inside the repository.

Our data model is also dependent on OdA's infrastructure. Each digital object in the repository is formed by three parts: its data, its metadata, and its resources. We have used these card sections to accommodate a simple card, an enriched card, and a list of resources attached to that item. At first, our intention was to introduce in the simple card the core fields that would be exported and shared with other networks, such as the CELL Project (http://eliterature.org/cell). But as the taxonomies of the CELL Project continued to develop to include very technical, objective data about the works in their core fields, we decided to keep our original distribution, at the same time that we made sure to include all the elements of the CELL taxonomy, though distributed in both the simple and the enriched card. This process has entailed a lot of metadata cleaning and revision to adapt Ciberia's data model to other collections of the Linked Data cloud, such as the CELL Project.

The simple card includes the title of the piece, its year of production, URL, a brief critical description, its genre, stylistic resources, theme, format, language and computer programs used in its construction. The enriched card contains more 
detailed information about the work, with especial emphasis in the modes of reading the work requires (we include here the physical devices or "mechanisms" required for exploring the piece, the procedural modes the work elicits and some reading instructions with a more philological orientation). The enriched card also includes other fields, like the details of collaborators' contributions to the work, festivals to which the work has been submitted, prizes obtained, critical commentary about the work, etc.

\section{Exploring Ciberia}

We have collected a small sample of 60 works to refine the data model. The selection was made trying to complement other directories as much as we possible, trying to introduce novelties as well as keeping a record of the most relevant works. So far we only have two types of entries, work cards and author cards, though we expect to include other categories in the future, such as other anthologies, general critical works, event announcements, etc.

The back office of Ciberia (fig. 2) can be accessed from the main page by administrators to maintain the website, add new digital objects and modify the data model. The system is incredibly flexible. These are the type of operations that it allows you to do:

- We can create new fields and new tags every time we need them, eliminate them, change their nature (open text fields, controlled vocabulary, etc.) or their location inside the taxonomy. You can also decide which fields are going to appear in the navigation menu (see fig.3).

- If we change the location of a field, everything that was classified using that field moves with it.

- You can lose data if you eliminate fields, but you can eliminate parent directories without losing data of the children directories, they will move to the parent level.

Fig. 1 - Ciberia's main page. 


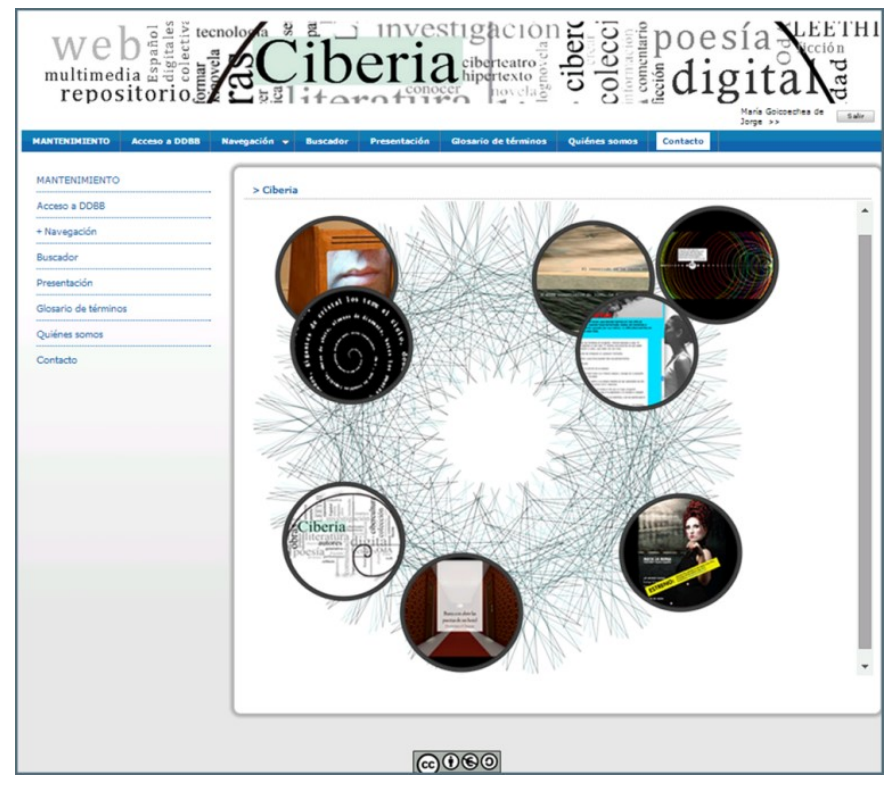

Fig. 2 - Ciberia's back office.

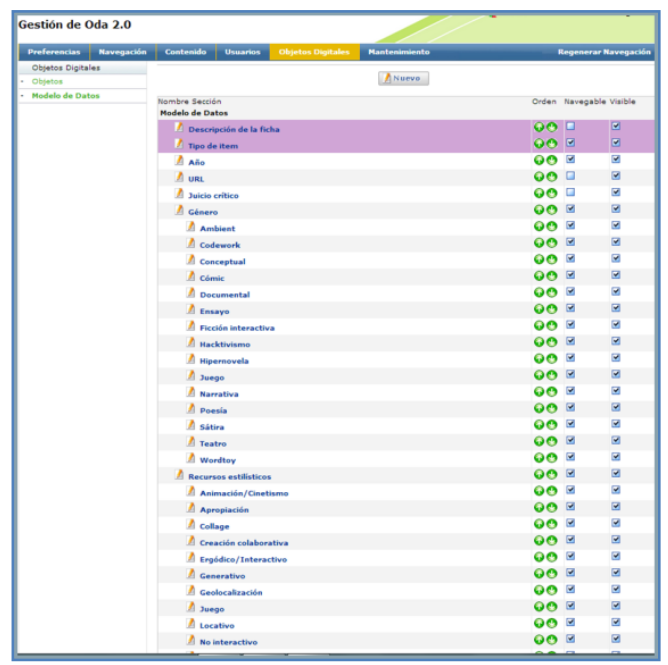

Fig. 3 - Navigation.

\begin{tabular}{|c|c|c|c|}
\hline \multicolumn{4}{|l|}{ Modelo de datos } \\
\hline F Guardar & & $<$ volver & \\
\hline Nombre: & Wordtoy & & \\
\hline Visible: & 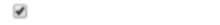 & & \\
\hline Navegable: & 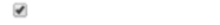 & & \\
\hline Extensible: & $\square$ & & \\
\hline Tipo de Valor: & \begin{tabular}{|l|} 
Controlado \\
\end{tabular} & & \\
\hline Vocabulario: & Vocabulario de Codework & & v \\
\hline Navegación padre: & Género & 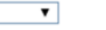 & \\
\hline q Guardar & & \& volver & \\
\hline
\end{tabular}


The search engine is a replica of the data model, so it allows you to filter data with a high-degree of complexity. A future addition will include a simple search field to explore the whole database contents, imitating a Google search.

\section{Author cards}

Obtaining as much data as possible from those artists who contribute to the development of the field is one of our objectives. They are still alive and we are lucky to know personally many of them, so we can check data with them and ask them to enrich our content with videos, written interviews, etc. From the author card we can access their work entries in the resources section and vice versa as they are crossreferenced.

Fig. 3 - Sample of author entry: Belen Gaché

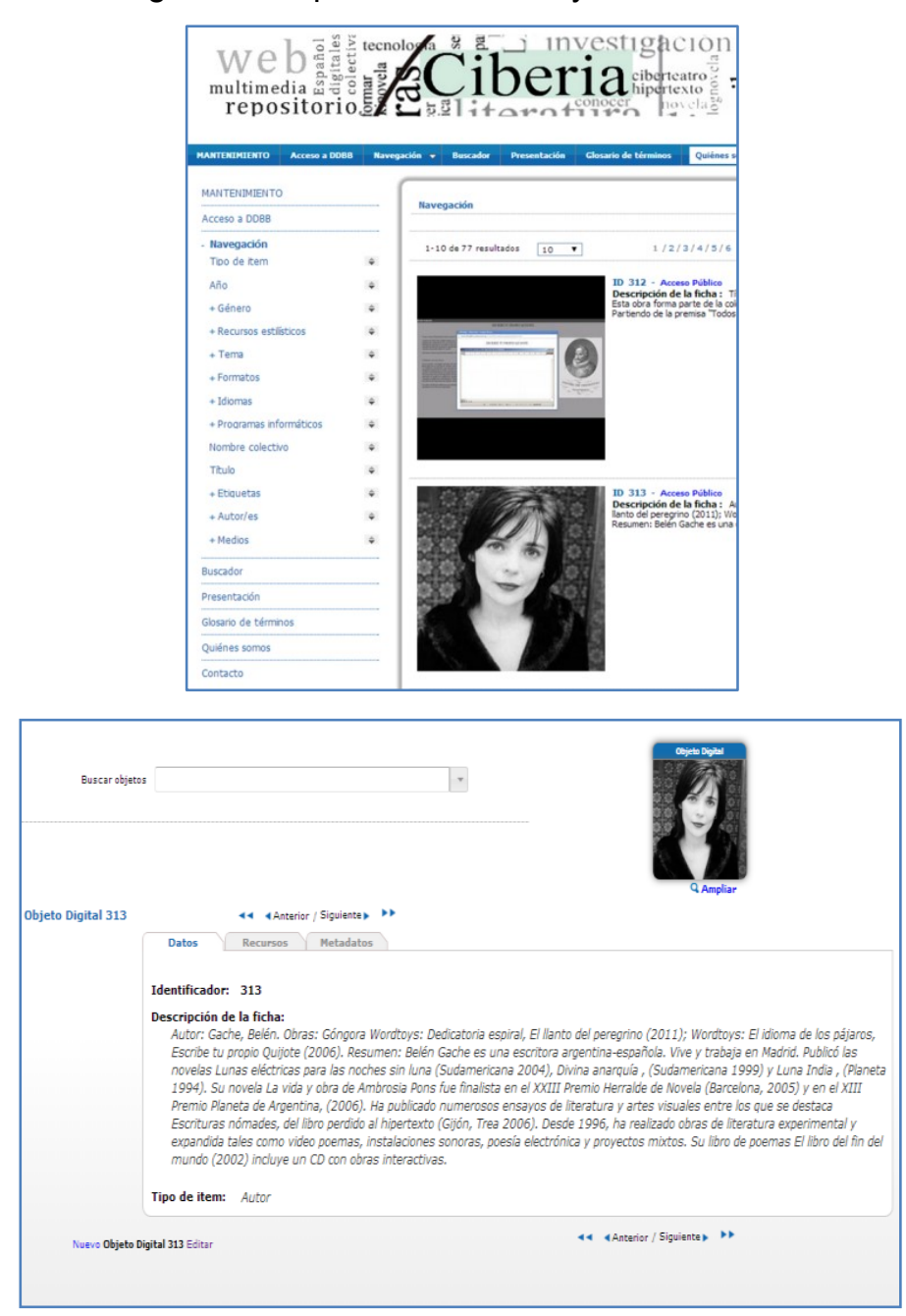




\section{Work cards}

Our aim is again to attach as much information about a work as we can. In the resources sections we provide links to online resources about the work and we want also to upload videos of reading sessions, especially of works under commercial license, lesson plans using that work, critical essays, etc. Among the features we would like to add in this section are specific instances of the work, both as screen captures or videos, in which their most distinctive characteristics can be observed. If a work has been tagged with certain tags that define it in terms of style or rhetorical devices, it would be very useful for researchers to be able to search for examples of 'retro-futurism' or 'contrapunctual sound' or specific hyperlink structures, and be able to access excerpts of different works where that specific device takes place or that style becomes apparent.

Fig. 4 - Sample of author card.

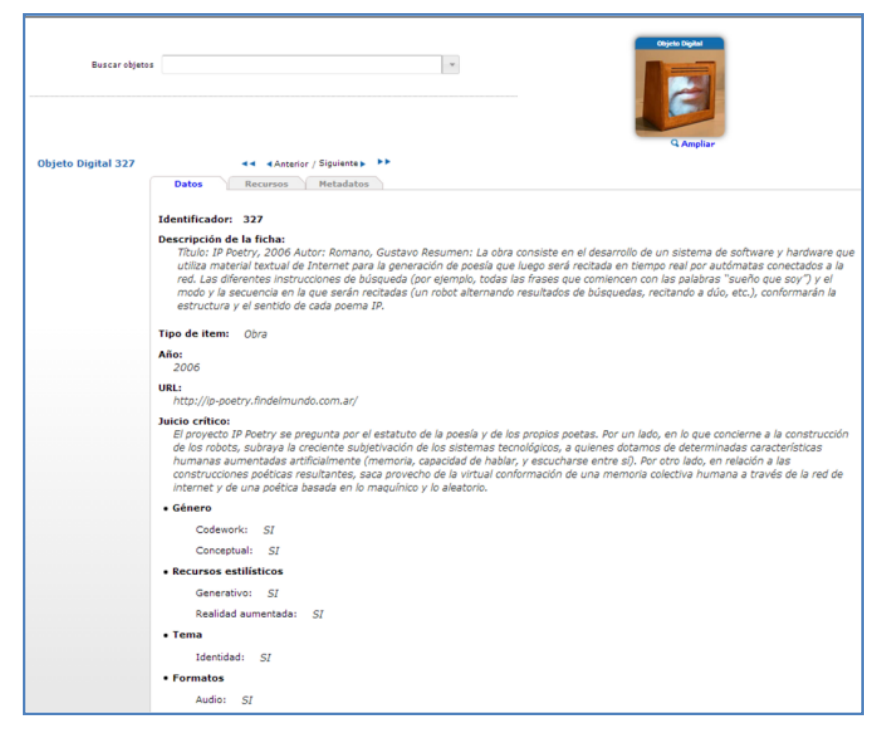

\section{Some highlighted entries}

Our main page will change its appearance to feature novelties or specially enriched material. At present, we have highlighted, for example, Domenico Chiappe's new work, Hotel Minotauro, still under construction, but we have a first version called 
Basta con abrir las puertas de un hotel. The interactive short movie Mindstorming, which has an English version, so it is one of our most accessible works for a general audience. It is a short movie that captures the encounter of a couple who has met chatting on the web and has decided to go on a date for the first time. You can access the thoughts of the man or the woman by interacting with the piece, moving an arrow left or right. This work challenges our categorizations, why should we include this as a type of e-literature if it is purely cinematic? Somehow we feel that the viewer's interaction with the video gives the piece a textual quality, or is it really its family resemblance with other works that compels us to treat it as a work of eliterature?

Fig. 5 - Mata la reina (2011) by Joctobit (left) and Mindstorming (2010) by Miguel Campos (right).

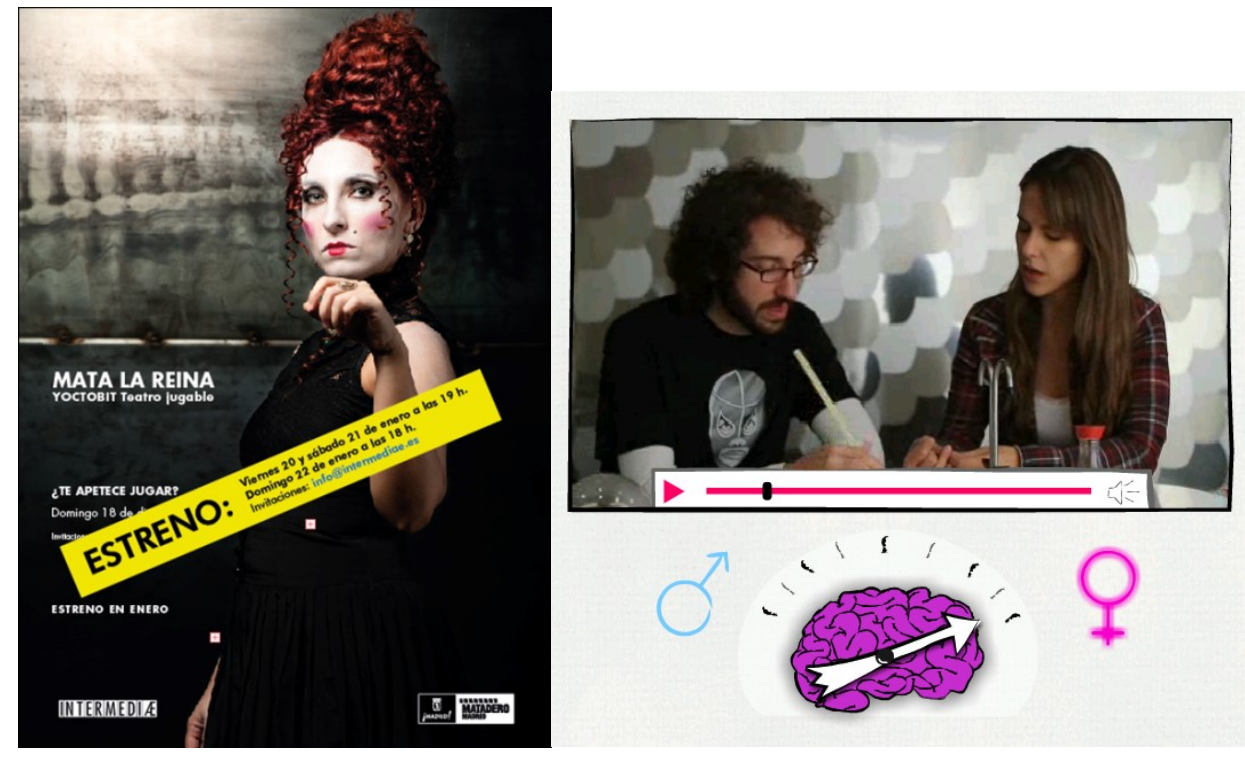

Another interesting proposal comes from Madrid's based collective Yoctobit, which emerged from the Media Lab El Prado. They are experimenting with hybrid creations that mix performance art and computer games. They have created a sort of playable drama, as they call it, a kind of interactive theatre that proposes to its spectators to either sit and experience the work in a conventional way or participate as actors within a dramatic game space where the final goal is to eliminate a tyrannical queen (the spectators can decide to remain passive or to join the resistance at any time, help the players collect the pieces of the puzzle that would help them to depose the queen and her four loyal soldiers, the only real actors on the set). The command is 
"kill the queen" but the queen is the only absent character. She lives in the computer program that also controls the soundscape, the light.

\section{Conclusions}

To conclude, we believe that this type of repository can help us create our own taxonomy, and adapt the database to the field we are describing. We do not have as many records as ELO Directory or the NT2 to consider the taxonomy stabilized. There are many categories which might not have any representative work in Spanish, and who knows, there might be new categories we will need to add, like "playable drama".

The works archived in Ciberia so far show interesting trends in the creations of artists writing in Spanish:

- We are recuperating the tradition of collective works. Particularly, we have found highly creative collectives emerging from media labs (like Intermediae, Medialab-Prado), signing their works under a collective name and developing their own aesthetic.

- We are quickly filling out a gap with other literary traditions where art, literature and technology have been historically more intertwined.

Moreover, the experience of archiving digital literature has shown us:

- $\quad$ The usefulness of finding programming spaces that facilitate collaboration in the creation of data models.

- $\quad$ The need for flexible data management systems that can assimilate a field that is in permanent change.

- $\quad$ The need to share information in ever growing networks. Thus, our future goal is to join the Cell Consortium and make visible our data about digital literature in Spanish.

Fig. 6 - Creators of Ciberia. 


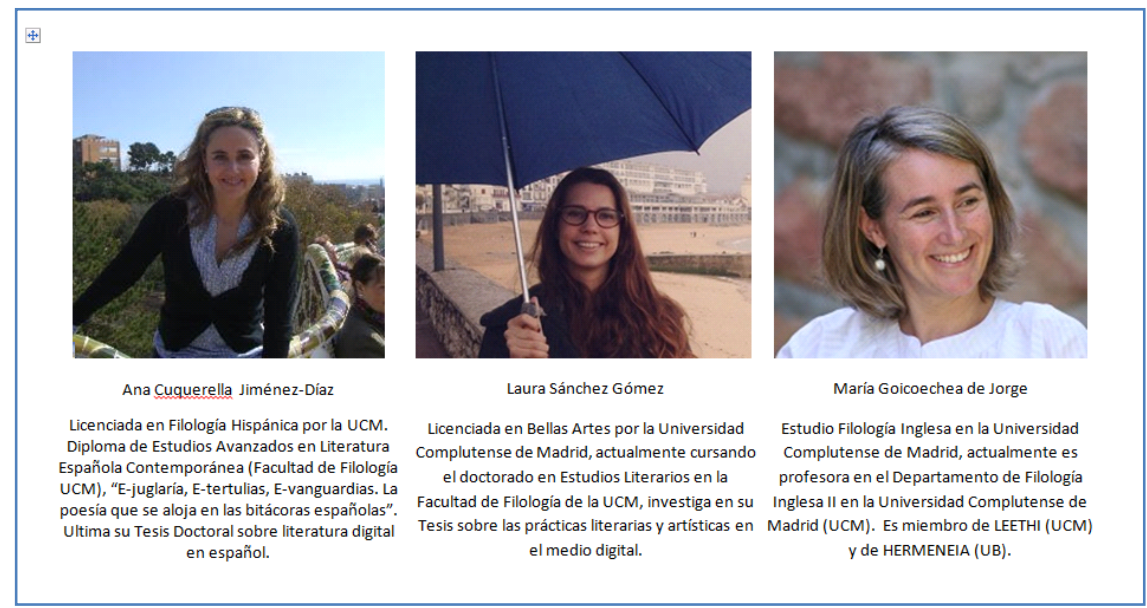

Hopefully, Ciberia's research and pedagogical functions will contribute to the CELL project with both an experience in digital literature archiving and with quality metadata that will make visible the peculiarities of Hispanic electronic literature's modes of creation and reception.

\section{O PROJETO CIBÉRIA: UM EXPERIMENTO EM HERMENÊUTICA DIGITAL}

RESUMO: Este artigo apresenta a "Ciberia", uma coleção de obras de literatura eletrônica em espanhol, hospedados em Oda 2.0, um repositório de objetos de aprendizagem da Universidad Complutense de Madrid. O projeto Ciberia envolve experimentação ao nível humanístico e tecnológico, uma vez que lida com o desafio de arquivamento de obras literárias nascidas digitais, bem como com o próprio processo de arquivamento, que estamos realizando em Oda 2.0, um sistema de gerenciamento de dados para a criação de repositórios de objetos de aprendizagem na Web. Oda permite que diferentes pesquisadores possam trabalhar de forma colaborativa de maneira simultânea na base de dados: podem não apenas introduzir novos objetos, mas também modificar o modelo de dados. Esta interação entre eles nos permite criar taxonomias em uma forma indutiva ao invés de uma forma dedutiva.O artigo aborda aspectos como os objetivos da coleção, a elaboração do fichamento bibliográfico da Ciberia, o processo de limpeza de metadados e reconciliação com outras coleções da nuvem de dados vinculados, como o Projeto CELL, e funções de investigação e pedagógica do Ciberia. Além disso, vamos mostrar algumas das suas obras literárias mais representativas enquanto vamos revendo o processo de criação da coleção.

PALAVRAS-CHAVE: Bibliotecas digitais. Ciberia. Hermenêutica digital. Banco de dados. Literatura digital. Literatura contemporânea espanhola.

\section{References}

CAPURRO, Rafael. Digital Hermeneutics: an outline. Al \& Society, n. 25, p. 35-42, 2010. Springer-Verlag, London Limited. 
Texto recebido em: 10/07/2015.

Texto aceito em: 28/07/2015.

Texto Digital, Florianópolis, Santa Catarina, Brasil, v. 11, n. 1, p. 4-20, jan./jun. 2015. ISSNe: 1807-9288. 